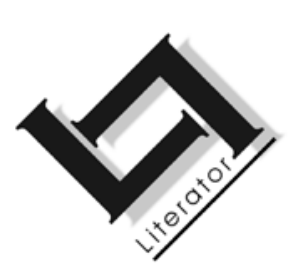

\title{
Vyf digters in gesprek met Joshua en Ian Marley se kreatiewe kreature
}

\author{
H.M. Viljoen \\ Navorsingseenheid: Tale \& Literatuur in die Suid-Afrikaanse \\ Konteks \\ Potchefstroomkampus \\ Noordwes-Universiteit \\ POTCHEFSTROOM \\ E-pos: Hein.Viljoen@nwu.ac.za
}

\section{Abstract \\ Five poets in conversation with Joshua and lan Marley's creative creatures}

This article analyses the reactions of five poets to Joshua and Ian Marley's creative creatures. Similarities and differences in the stimuli the poets react to, the ways in which they imitate the creatures morphologically, the patterns, names, Gestalts, scripts and archives they use to understand the creatures as well as their unique reactions are analysed. The poets are creative in the patterns they recognise and the ways in which they try to fit the creatures into known frames, wholes, names and scripts. The poems, however, also demonstrate strong techniques for containing these creatures and making them less threatening. In the end a few conclusions on creativity in these cases are formulated, namely that creativity is a mixture of iconising, pattern recognition (recalling familiar frames, scripts and archives) and naming and unnaming (efforts to describe the creatures wittily). A tension between creativity and making comes to light when one reads the poems against the background of Horatius' norm of decorum.

\section{Opsomming}

\section{Vyf digters in gesprek met Joshua en lan Marley se kreatiewe kreature}

Hierdie artikel ontleed die reaksies van vyf digters op die kreatiewe kreature van Joshua en lan Marley. Die ooreenkomste en verskille in die digters se keuse van stimuli, die wyse waarop 
hulle die diere morfologies naboots, die patrone, name, gehele en skrippe waarop hulle ' $n$ beroep doen om die kreature te verstaan (en te besweer) en die unieke reaksies van die digters word agtereenvolgens ontleed. Die digters is kreatief in die maniere waarop hulle patrone herken en die diere probeer inpas in bekende raamwerke van gehele, name en ook storiekerns (skrippe). Andersyds bevat die gedigte egter ook sterk maniere waarop die digters die diere probeer besweer of minder bedreigend probeer maak. Aan die einde word 'n paar gevolgtrekkings oor kreatiwiteit geformuleer, naamlik dat kreatiwiteit hier 'n mengsel is van ikonisering, patroonherkenning (die oproep van bekende rame, skrippe en argiewe), en benoeming en ontnoeming (pogings om die diere vindingryk te verbaliseer). 'n Spanning tussen kreatiwiteit en gemaaktheid kom aan die lig indien 'n mens die gedigte lees teen die agtergrond van Horatius se eis om dekorum.

\begin{abstract}
Humano capiti cervicem pictor equinam iungere si velit et varias inducere plumas undique conlatis membris, ut turpiter atrum desinat in piscem mulier formosa superne, spectatum admissi risum teneatis, amici?
\end{abstract}

(Horatius, 1990: v. 1-6.)

\title{
1. Pynappel - of dalk eend?
}

"Dis 'n bokserhond," sê die een, "gestreep soos 'n streepsak." "'n Streepsak het g'n strepe nie," sê die ander, "buitendien, sy dop is pure skilpad." "Beslis 'n bokserhond." "Nee," sê die derde, "beslis 'n skilpad. Kyk na die pote. En hy't 'n lepelklepelknyper op sy kop." "Is nie," sê die eerste, "dis 'n venusvlieëvanger." "'n Tenk met 'n veertjie in die hol. Heel modern," antwoord die tweede. "Buiten waar dit nie 'n hond is nie, beslis 'n bokserhond," besluit die eerste.

Amper so, kan 'n mens jou voorstel, raak die digters aan die stry oor die reeks van nege vreemde kreature wat Ian Marley geteken het na idees van sy seun, Joshua. Hierdie vreemde kreature is, as deel van die navorsingsprojek oor kreatiewe kreature, as stimulus voorgelê aan 'n groep kunstenaars, waaronder 'n paar digters. 1 Nes die ander kunstenaars het die digters hulle reaksies onafhanklik van mekaar geskryf. Hulle was ook nie bewus van die name van die

$1 \quad$ Kyk Greyling \& Marley (2009:1-29) se artikel voorin hierdie nommer vir meer detail oor die projek. Die tekste volg agterin hierdie nommer, in die Literaafdeling. Die sketse is opgeneem op p. xix-Xxvii. Kyk ook in die ingeslote kompakskyf. 
kreature nie. Hulle reaksies verskil baie, maar daar is ook 'n paar opvallende ooreenkomste. Die vraag is natuurlik: hoekom reageer hulle so verskillend? Het hulle ooit poësie van hierdie beelde gemaak gekry? Les bes, sou die leser uit hulle reaksie iets oor kreatiwiteit kon aflei?

Reeds na 'n eerste deeglike lees van die versameling tekste deur Hans du Plessis, Heilna du Plooy, Sanko Lewis, Hein Viljoen en Hennie van Coller kan hierdie reeks vrae verfyn word tot 'n stuk of vyf:

1. Op watter stimuli reageer die digters, met ander woorde watter elemente van die kreature selekteer hulle om in hulle gedigte te gebruik?

2. Wat maak hulle met daardie stimuli? Hoe verwerk hulle dit? Watter patrone, rame of skrippe herken hulle?

3. Watter ooreenkomste (gemeenskaplike elemente) en watter verskille is daar in hulle reaksies (of resepsies)?

4. Hoe kontekstualiseer hulle die kreature ten einde hulle te verstaan?

5. Kan 'n mens uit hulle reaksies iets aflei oor kreatiwiteit in die algemeen?

In die bespreking wat volg, sal ek hierdie vrae probeer beantwoord. My benadering is veral induktief, naamlik dat ek uit die lees van die gedigte sekere afleidings maak en 'n paar teoretiese begrippe invoer om hierdie afleidings mee te benoem. Vir die duidelikheid sal ek in my bespreking Joshua se name vir die kreature gebruik soos hulle in die katalogus (Van der Westhuizen et al., 2007) voorkom. Die digters sal ek by hulle vanne noem, maar dan as 'n afkorting vir byvoorbeeld "die spreker in Hans du Plessis se gedig", omdat ek maar te bewus is van die feit dat die spreker in die gedig nie gelykgestel kan word aan die digter self nie. Die spesifieke gedig sal ek met sy titel aandui en, waar nodig, versnommers verskaf.

\section{Keuse van stimuli}

Daar is redelike sterk ooreenkomste in die stimuli waarop die verskillende digters fokus, maar hulle interpretasies en verstaan van daardie stimuli loop nogal uiteen. Vlerke, sterte, koppe en bekke trek die meeste aandag by Du Plessis. Oor die algemeen is dit die aanhangsels of ledemate van die kreature wat die meeste varieer en die 
digters registreer dit ook so, hoewel natuurlik nie altyd in dieselfde mate en altyd ewe prominent nie. Vir Du Plooy val die kreature se skerp kloue op, maar Viljoen gee konsekwent besonder baie aandag aan pote en kloue: "poot" kom vyf keer in verskillende vorms voor, "klou" vier keer en "hoef" en "web" elk een keer. Pote is uiteraard die ledemate waarvan daar die meeste variante in die sketse voorkom.

Lewis is oor die algemeen meer bewus van die strepe en kolle van die kreature as die ander en beskou byvoorbeeld Canny as 'n bokserhond "gestreep soos 'n streepsak". Van Coller herken wel W.P.-kleure in Ostrigy se gestreepte nek en praat van Ducky se ringnek. Viljoen maak daarvan bloedrooi bande wat deel vorm van die kreatuur se paringsdans. Almal behalwe Du Plessis noem Canny se kanon maar beskou dit as 'n periskoop en net Lewis ("energiegeweer" maar ook "periskoop") en Viljoen ("laser") herken dit as 'n soort wapen. Viljoen, Van Coller en Lewis sien ook Canny se eienaardige kloue raak, maar Van Coller praat van 'n "lepelklepelknyper" terwyl die ander twee 'n venusvlieëvanger daarin herken. Opvallend is dat Viljoen en Van Coller albei Rhino se waardigheid sowel as sy rimpels raaksien - en natuurlik ook sy horing. Van Coller lewer, anders as Viljoen en Du Plooy, egter geen kommentaar op sy vlerkies nie.

Die digters gee wel dikwels aandag aan die oë, maar beklemtoon nie die oë altyd so sterk soos wat Joshua in sy beskrywings doen nie (vgl. Van der Westhuizen et al., 2007). Die uitsonderings hier is Du Plooy, wat meen dat almal "vreemd en verskriklik goed [kan] sien" - 'n fokus wat Viljoen deel, want hy gebruik die woord "oog" ses keer. Al word die oë dikwels geregistreer en is bekke, snoete en selfs snaters volop, word die kop of die gesig selde genoem. Die uitsondering is Van Coller wat die periskoopkop van Canny noem, Vampire se slange vergelyk met gesigshare en praat van Wolfie se "nare wolfgesig". Viljoen is die digter wat die gepantserde aard en die monsteragtigheid van die kreature die sterkste beklemtoon. Van Coller praat wel van "wanstaltige lote" en beskryf Fishy as 'n "hibried", maar Viljoen is meer uitgesproke hieroor met woorde soos "gedrogte", "monster" en "horries". Die titel wat hy vir sy reeks tekste kies, "Kwintzillas", is ook 'n sinspeling op Godzilla, die rolprentmonster wat in 1954 deur die Japannese filmmaatskappy, Toho, uitgedink is en sedertdien Japan gereeld besoek en alles vernietig wat voorkom. Sy Japannese naam, Gojira, is 'n samestelling van "gorilla" en die Japannese woord vir walvis, "kujira". Hy is egter nie 'n kruising tussen die twee nie, maar eerder 'n fiktiewe soort dino- 
sourus wat na miljoene jare uit sy slaap gewek is deur atoombomtoetse (Goldberg, 2008:FAQ).

Opvallend is dit dikwels egter die "material bodily lower strata" (Bakhtin, 1984:370) waarop die digters die klem laat val - baiekeer ook as 'n soort satire van die kreatuur of om die bedreiging van die kreatuur te besweer. Veral Van Coller se vernufspel ontluister dikwels die kreatuur deur op sy laer liggaamlikheid te wys of verskillende verwysingsrame te laat bots. Vampire lyk vir hom nie soos 'n superheld nie, maar eerder of hy 'n nood het. Rhino se waardigheid kontrasteer hy met 'n skeur in 'n fluweelbroek. Hy noem Choppy 'n eienaardige "leepooggeslyptebeitel reun" en ontluister die hele affêre met 'n sinspeling op kastrasie. Wolfie laat hy "boontjiesopskote" los en Fishy beskryf hy as "'n vis op steroïede". By Viljoen is daar dieselfde tendens. Hy kontrasteer Rhino se vlerkies met sy "swaar ou gat". Ostrigy se swaar stert sleep hom af grond toe. Choppy moet homself op die boud skop. Canny het 'n "veerpen in die hol". Dit is egter Lewis wat in sy "Skets 2" hierdie "beginsel van groteske realisme" (Bakhtin, 1984:370) die verste voer, soos hieronder sal blyk.

\section{Morfologie en Ikonisering}

'n Baie opvallende kenmerk van die digters se reaksie is dat hulle die kreature morfologies naboots. Van Coller noem Fishy 'n "[h]ibried glo uit diverse biologiese gebiede". Maar net soos die diere bestaan uit ongewone kombinasies van bekende elemente (of vorms) van verskillende diere - sterte, bekke, pote, oë, lywe, vorms, kolle, ensovoorts - speel die digters met ongewone kombinasies van woordelemente. Woorde word in verskillende vorms afgebreek en op ongewone maniere geherkombineer. In heelwat van die gedigte vind ' $\mathrm{n}$ mens hierdie tendens, wat ek morfologiese ikonisering sal noem.

Du Plessis druk byvoorbeeld die seem "deurmekaarheid" op hierdie wyse uit, en skryf "deurmediere" wat so "kaarmedeur" proe, of noem Rhino 'n "rhinoture". Hy gebruik vreemde vorms soos "eventature" en "creatature". Sy teks is net soos die kreature self 'n hibriede vorm van die sonnet waarin hy onder andere met rekenaartaal en die agterstevoor gebruik van hoofletters en leestekens iets van die vreemdheid van die diere uitdruk. Voor en agter word omgeruil - in die sinne ook, want hulle begin met 'n punt en eindig met 'n hoofletter. Opvallend is ook dat hy sinestetiese beelde of kontradiktoriese frases gebruik om die deurmekaarheid van die diere ook semanties uit te druk: hulle ruik "na vlerke" of hulle "bekke ... klink 
stinker as hulle nekke". Deurmekaarheid kry ook op verskillende vlakke gestalte: in semantiese onversoenbare frases en in die vorm van die teks self, al bly hy ook by die rymskema van 'n sonnet. Die ikoniese morfologie werk by Du Plessis dus saam met verskillende ander vlakke van die teks om die idee van deurmekaarheid uit te druk.

Die minste morfologiese ikonisiteit kry 'n mens by Du Plooy. Sy gebruik wel 'n paar samestellings om iets van die vreemdheid uit te druk, naamlik "wonderdiere" en "stekeltongpadda". 'n Ander afwykende vorm is "donkerlik", vermoedelik as 'n soort rym op "wonderlik". Du Plooy is egter veel meer begaan oor die ruimtes en omramings waarin die diere geplaas word en die spreker in die gedig se assosiasies met verwante matryse en seme.

Van Coller gebruik betreklik min morfologiese eksperimente. Hy vorm veral samestellings as deel van 'n poging om die kreature te benoem, vergelyk samestellings soos "eenoog-eend", "Siamese paddapaar", "pynappel wolf". Morfologies interessant is wel die naam "Ollinoster" en veral die benoeming "leepooggeslyptebeitel reun", waarmee hy trag om twee van die vernaamste eienskappe van Choppy saam te vat. Opvallend in sy beskrywing van Canny is ook die baie samestellings - "skilpaddop", "periskoopkop", "lepelklepelknyper". Laasgenoemde twee is albei moeilike en atipiese kreature wat groot uitdagings aan die kyker se begripsvermoë stel. By Van Coller vind ' $n$ mens dus meestal nie morfologiese ikonisiteit nie, maar hy probeer wel kernagtige en tekenende saamgestelde name aan die kreature gee - probeer hulle dus met samestellings vasvat. Benoeming is by hom 'n sterker imperatief as ikonisering.

Dieselfde geld vir Viljoen se tekste, hoewel sy benamings vir die kreature 'n groter appèl op vreemde kombinasies maak. Voorbeelde daarvan is "Vlernoster", "Ganskiloop", "Pantservorste", "Voëlvis" of "Eendpadtenk". By hom is daar, soos by Van Coller, 'n poging om die kreature kernagtig (en dalk selfs potsierlik) te beskryf en hulle essensies en belangrike eienskappe vas te vang in nuwe en ongebruiklike samestellings. Hierdie samestellings bring juis die onversoenbaarheid of ongerymdheid van die samestellende dele sterk na vore, wat daarom ook ikonies van die kreature se eienaardige anatomie is. Die samestellings kry dikwels 'n metaforiese kwaliteit, soos in "ganstrot" of "horrieriem". "Ganstrot" heraktiveer die dooie metafoor versteek in "foxtrot" en bring ook die kontras tussen 'n gans en ' $n$ jakkals se draf na vore. Die metafoor onderstreep juis die ironiese nabootsing van menslike gedrag. 
In sy eerste vier sketse is Lewis veral begaan oor dele en gehele en probeer hy die kreature benoem met samestellings en metaforiese naamwoordfrases soos "springmielie", "tronkvoël in skaapsklere", "koushandpop", "frieskoei-maagsak", "windwyserveertjie", "knopkieriekop" ("Skets 3"). Hy laat die klem dus val op die fabriseer, die doelbewuste maak van gehele, net soos die speelgoedvlerke "gefabriseer [is] met draadhangers en kougom" ("Skets 3", v. 21-22).

Dit is egter in "Skets 4" dat Lewis die vreemdheid van Vampire opvallend sterk morfologies naboots:

ek is bebek

met bekkige bekke

(bek bekker bekste)

op oralste plekke

my bekke gaap soos oë

my oë hap soos bekke

my bekke knipoog

my ogerste oë byt

ek is vampierste-vamste-pier

ek's 'n dier uit Daniël-en-Openbaring:

By "bebek" kan ons ook lees "bedek". Die bekke word baie sterk vooropgestel deur herhaling, maar ook deur ikoniese morfologie. Vreemde, niestandaardvorme word gebruik, soos die trappe van vergelyking wat van "bek" gemaak word. Die morfologiese vervorming in woorde soos "bekste", "bebek", "ogerste" en "vampierstevamste-pier" versterk die idee dat die kreatuur sowel bedreigend kyk as dreig om te hap. Bek en oog word vermeng - ook in hulle eienskappe en kenmerkende aksies. Gaap, hap, knipoog, byt word uitruilbare aksies vir bek en oog in 'n soort sinestesie. Bek en oog word dus saamgedink as 'n soort allerbedreigendste kenteken of signatuur van die kreatuur - 'n signatuur wat op sy vlerke en skoene voorkom en ook in sy gesig herhaal word en verder deurwerk na die "groot dinge" wat die mond aan die einde van die gedig spreek. Hier gebruik Lewis onder andere die morfologie om 'n bedreiging op te roep wat die verstand en die gewone konsepsie te bowe gaan.

\section{Dele en gehele: patrone, name, verwysingsrame en argiewe}

Gewone konsepsies speel andersyds 'n groot rol in die digters se reaksies. Om bekende patrone en gehele in die kreature te herken en hulle name te gee, is waarskynlik die beginpunt vir die beskry- 
wing van die diere. Dit word natuurlik baie interessant as die kreatuur nie gemaklik in een spesifieke bekende patroon of raam 2 inpas nie en die digters verskillende name en verwysingsrame oorweeg om sin te maak van die onbekende dinge wat die visuele tekste aanbied.

Sommige patrone (of Gestalts ${ }^{3}$ ) lê redelik voor die hand, soos om 'n renoster in Rhino te herken, paddas in Froggies of ' $n$ vampier in Vampire (soos Joshua se name reeds aandui). Viljoen en Van Coller toon hulle Nederlandse kennis deur Froggies met die Nederlandse naam vir 'n padda, kikvors, te benoem. Ander kreature is egter moeiliker benoembaar, en uit hierdie oogpunt dus interessanter.

Die gehele van gans of eend is in Ducky en Ostrigy op die spel. Van Coller sien in Ducky 'n "eenoog-eend" maar ook 'n Middeleeuse draak, waarskynlik danksy die stert. Viljoen beskou Ducky as 'n vermenging van 'n gans en 'n sikloop en plaas die kreatuur daarmee teen 'n sterk mitologiese agtergrond. Hy stel die dier self aan die woord en dan wel as 'n sensuele pronker wat 'n paringsdans voor die blom uitvoer. Hy beklemtoon die gedrag en skryf kleurveranderings aan die verliefde dierasie toe wat die blom kennelik probeer verlei tot 'n sensuele dans - 'n dans wat egter, anders as die vinnige, sensuele foxtrot vanselfsprekend 'n waggelrige ganstrot sal wees. Viljoen lê ook sterk klem op die parmantige, pronkerige sjarme waarmee die dier by die blom aanlê. Al is die gedig ' $n$ sjarmante voorstelling, ontluister dit ook die gedrag van die dier as potsierlik en oordrewe - belaglik verlief; uitgelewer aan sy biologiese paringsdrang; oorbewus van hoe sexy hy is. Die baie herhaling en die sangerige aanslag van die gedig onderstreep die oordrewe (maar vergeeflike) sjarme van die dier.

Lewis gaan op soek na name vir die geheelprentjie in Ducky en noem verskillende Gestalts daarvoor op: springmielie, katoen,

2 Raam is Minsky (1975:96) se term vir 'n datastruktuur wat 'n stereotipiese situasie, soos 'n kinderpartytjie (of soos hier, 'n sekere dier) voorstel. Dit bestaan uit 'n netwerk van knope en verhoudings, met algemene inligting bo-aan die netwerk en meer spesifieke inligting onderaan. Sekere inligting is voorspelbaar aanwesig, die sogenaamde verstekwaardes. Vergelyk Viljoen (1987) vir 'n literêre toepassing daarvan.

3 Duits vir "vorm" of "gestalte". Dit dui 'n struktuur of patroon van verskynsels aan wat geïntegreer is in 'n funksionele geheel sodat die eienskappe van die geheel nie uit die dele afgelei kan word nie (Merriam-Webster Online Dictionary, 2009). Ek dui met die term veral die geheel van die verskillende dier-stereotipes aan. 
"tronkvoël in skaapsklere". Sy vertrekpunt is Ducky se opvallende wollerige lyfbedekking en die strepe om sy nek, wat vir hom ook tronkdrag aandui. Die eendagtigheid is vermoedelik die skakel met die kinderliedjie "Eendjies eendjies, stap hul in 'n ry", wat hy tussen die reeks Gestalts invleg. Die reeks raak al hoe fantastieser tronkvoël in skaapsklere, likkewaan, lelike swaan, man-in-die-maan. Die rym op -aan ("likkewaan", "swaan", "maan"), saam met die rymklanke van die liedjie, is hier 'n belangrike leidraad en kreatiewe instrument. Die reeks Gestalts skep assosiasies met kinderlikheid maar ook met die sprokie van die lelike eendjie, en dit lyk asof die digter daardeur van die dier sin probeer maak en hom tewens wil besweer en in fantasie laat vervaag.

In Ostrigy het nie een van die digters 'n volstruis herken nie: Viljoen en Van Coller sien albei 'n gans in hom en Lewis herken ook sy ganspote. Aan sy kolle herken Van Coller en Lewis 'n frieskoei, maar Van Coller fokus meer op die strepe om sy nek, waarin hy W.P.-kleure herken. Die nek en die stert is vir Viljoen en Van Coller ewe opvallend, maar hulle koppel totaal ander Gestalts daaraan: Van Coller sien "'n brandsiek perdehings se stert" en Viljoen 'n swaar "pantserstert".

By Lewis kry ons 'n besonder interessante vermenging van Gestalts. Hy noem die kreatuur 'n "frieskoei-maagsak" en lê klem op sy bewegings: "trap met ganspote", "klap soos 'n moffie die lug" - waarskynlik 'n reaksie op die yl manier waarop die linkerpote geteken is. Viljoen lê ook klem op die dier se bewegings en probeer iets van sy gevoel en (poging tot) vlieg vasvang, maar meen dat sy eienaardige samestelling - die kontras tussen klein vlerkies en swaar stert vlieg vir hom onmoontlik maak.

In sy tweede strofe verdeel Lewis die kreatuur in verskillende ander gehele van die laer liggaam: balsak, penis en hol, wat dan 'n selfstandige lewe begin lei, maar met hulle buitengewone ledemate ook uitreik na die hoëre. Hy ontbind Ostrigy dus in elemente van die laer menslike liggaam wat direk tot vreemde vorms uitgroei:

as balsakke vlerke kry,

as penisse tronkvoëlnekke en eendbekke kry,

as holle sterte met horings kry,

my kind - hang nie rond nie!

Juis hierdie verbinding van die laer liggaam met ongewone hoër uitgroeisels maak dié kreatuur besonder bedreigend. Dit is asof die laer liggaamlike strata dreig om alles te oorweldig; om gevaarlik uit 
hulle gewoonlik versweë of onderdrukte staat te ontsnap. Die gewone werfgans dreig om te ontbind in swewende geslagsorgane.

Dit is opvallend dat Lewis veral die kolle en strepe saamvat as gehele: frieskoei, tronkvoël, die harigheid van die kreatuur as balsak. Hy fokus ook op die vorm van die maag: om dit 'n balsak te noem, is nogal 'n gesogte siening van die vorm van die maag, al lyk dit duidelik soos 'n sak en het dit wel 'n opvallende ronding vooraan. Die geslag van die dier is ook by hom dubbelsinnig: hy noem dit 'n koei en later 'n balsak. Vir Van Coller is die dier manlik (hoewel met 'n "Frieskoei-lyfie"), maar Viljoen noem haar "Moedergans" - 'n sinspeling op die bekende sprokiesfiguur en dalk ook 'n persoonlike assosiasie met Hera en die gans in Sheila Cussons se poësie.

'n Ander interessante geval is Wolfie. Viljoen en Van Coller herken albei die Gestalts van die pynappel en die wolf in hom. Albei fokus ook op sy pote. Albei digters probeer ook skynbaar iets uit die houding van die dier aflei - maagpyn of onbeweeglikheid. In sy vag herken Viljoen rosette, wolwiele of wolwronge en suggereer ook skaapsklere in die titel. Hy besweer egter enige bedreiging wat die dier kan inhou deur Wolfie bewus te maak van sy eie onvermoë om te beweeg en hom dit selfironies te laat beskryf met die filosofiese konsep van die onbeweeglike beweger, die oorspronklike eerste oorsaak van alle lewe en beweging by Aristoteles.

By die interessante toetsgevalle van Canny en Choppy moes die digters heelwat kreatiewe spronge maak. Van Coller herken wel ooreenkomste tussen Choppy en ander gehele en is dus as 't ware op soek na 'n gepaste geheel. Hy noem eers hings, dan beitel en derdens hond, en dit is die hondagtigheid wat dominant raak, soos blyk uit die woorde "reun" en "tefie". Verder plaas hy die kreatuur vernuftig in die raamwerk van paringsgedrag van honde, maar dan met 'n sinspeling op 'n vraag soos "how do porcupines make love?" Geestig onderstreep hy dus die risiko's van paring en liefde en maak die kreatuur ook effens belaglik en dus relatief onskadelik (behalwe natuurlik dan vir sy eie soort).

Viljoen sien aan Choppy die pote van 'n sebra en 'n eend raak, maar pas die geheel in die bekende patroon van 'n miervreter met ' $n$ skerp bek soos 'n skeerbekmuis. Sodoende maak hy dit bekend en minder bedreigend. Hy stel die dier ook voor as bewus van sy eie "vreemde samestelling", en maak asof dit van sy kykers simpatie probeer kry. 
Die vreemdheid word in die tweede deel van die gedig verder beklemtoon. Om die lugskag in die raam van die miervreter in te pas, maak die kreatuur uiteindelik logies onbestaanbaar of onmoontlik binne die raam van soogdiere (wat hierdie een waarskynlik ook is). Die rede daarvoor is dat hy homself skynbaar op die boud kan skop (soos die merke op sy boud - vir Viljoen hoefmerke - suggereer). Die kreatuur is dus effens belaglik, wat die aandag van sy bedreigende bek aflei. Hy word dus nie as bedreigend ervaar nie, maar eerder as vreemd en onlogies.

Van Coller noem Canny 'n "Skilpad met periskoopkop" en lys dan sy vernaamste eienskappe op 'n wyse wat die Gestalt van die skilpad algaande ondermyn en die spreker "verbyster" laat. Viljoen benoem dit met 'n dubbele samestelling, "Eendpadtenk", wat drie Gestalts probeer saamtrek en sin maak van die geheel deur dit as 'n geheime wapen, toegerus vir alle gebeurlikhede, te beskou - 'n soort science fiction-raam waarin die dier se vreemde aanhangsels wel kan pas. Die dier is kennelik gevaarlik en weerbaar, maar word tog effens belaglik voorgestel deur sy week stertversiering 'n veerpen te noem - 'n baie outydse stuk tegnologie, sterk in kontras met die gevorderde tegnologie van die res. Dit sluit egter wel aan by die Gestalt van die skilpad: eweneens nie danig vinnig of modern nie.

Lewis vestig, interessant genoeg, aanvanklik 'n sterk Gestalt, naamlik die bokserhond, maar ondermyn en bevraagteken dan daardie aanvanklike identifikasie. Globaal plaas hy die hond-gestalt op die voorgrond, maar ontken dit terselfdertyd ook deur die elemente op te noem wat daarmee onversoenbaar is. Hy maak die streepsak letterlik en noem fyn detail op wat telkens die Gestalt twyfelagtig maak: "geraamte-arms", "kloue", "Venusvliegvanger". Hy gaan op soek na verskillende benamings vir die veertjie op die stert:

Ja, buiten vir die oliekannetjie

met ' $n$ windwyserveertjie

soos 'n vlaggie op 'n bergpiek,

nee, dis 'n paddavisstertjie,

nee, 'n kersie op 'n koek,

nee, 'n pluimpie op 'n verjaarsdaghoed;

Die aanvanklike bedreiging van die dier word dus speels omgekeer en die klem val sterk op die gemaaktheid van die dier - ook in 'n kinderlike, speelse sin, soos 'n onhandige prakseersel vir 'n kind se skoolkonsert.

Elke keer kom 'n nuwe eienskap by, en die spreker spekuleer oor verdere moontlikhede om sin van die geheel te maak. Die manier 
waarop hy die eienskappe uitbrei, vestig ook die aandag op verskillende verhale waarin die geheel sin sou maak: "skoolkonsert", "outannienek", "knopkieriekop", "makoubek", "energiegeweer", "periskoop". Daardeur raak die geheel egter steeds verder gefragmenteer en onbegryplik. Die aanvanklike geheelinterpretasie raak dus gaandeweg al hoe onwaarskynliker en die dier daardeur al hoe vreemder en onbegrypliker. Die bedreiging wat dit aan die begin ingehou het, verdwyn mettertyd as 't ware in die uitsaai van eienskappe en nuwe moontlike verhaalkerns.

By Van Coller is dit duidelik dat hy ook groter rame gebruik en die kreature veral ook met literêre intertekste verbind. Dit sluit rame uit die gewone lewe in. Fishy het Cadillac-neusgate en baie oë vir tvkyk. Ostrigy dra vir hom rugbykleure en Rhino lyk vir hom soos 'n APK-koster, dit wil sê ernstig en konserwatief. Dracula verstaan hy as 'n onbeholpe moderne superheld in die tradisie van Spiderman. Meer literêre rame is die Middeleeuse draak wat hy in Ducky herken en die herinnering aan A.G. Visser se beskrywing van 'n olifant wat 'n mens in sy "Pynappel wolf" kan hoor ("'n ringetjie van agter en een van voor"). Froggies probeer hy in die raam van die belydenispoësie van die Dertigers inpas deur die opvallende rûe van die paddas te assosieer met die woorde "ruggelings stort" - woorde uit Van Wyk Louw (1981:84) se gedig "Miskien ook sal ons sterwe" uit die reeks "Gedagtes, liedere en gebede van 'n soldaat". Hy herken dus ook iets van die soldatekonteks in hierdie kreatuur, maar die Dertiger-assosiasie bly gesog. Deel van die vernuf wat Van Coller egter demonstreer, is dat hy die kreature binne geleerde sowel as populêre rame plaas.

Viljoen plaas sommige van die kreature teen 'n vaerige mitologiese agtergrond met 'n beroep op onder andere moedergans, die sikloop, Dracula en Medusa. Deur Vampire met Frankenstein te assosieer, plaas hy die maak van die kreature enigsins in die raam van rasioneel-tegnies vervaardigde monsters en die gedrogte waaraan daardie droom van die rede geboorte gegee het, net soos in Goya se Capricho 43, "The dream/sleep of reason produces monsters" (Hofman, 2003:85). 4

$4 \quad$ Hofman (2003:73) skryf ook dat die kapries nie net 'n skielike kreatiewe bevlieging is, en dus kreatiewe vryheid verteenwoordig nie, maar ook 'n donkerder kant het wat vrees en gruwel opwek; nie net marginale figure soos drinkers of storievertellers uitbeeld nie, maar ook donker dinge soos maskers, geeste en "infernal and diabolical representations". 
Lewis probeer met 'n opvallend groot verskeidenheid rame sin aan die kreature gee. Die uitbreiding van assosiasies, Gestalts en rame is 'n beginsel van kreatiwiteit by hom. Hy en Viljoen assosieer albei Vampire met 'n dier uit die apokalips, naamlik die dier met die horings uit Daniël 7. Dit is die vierde dier uit die see wat 'n simbool is van 'n koninkryk wat sal "verslind", "vertrap" en "verbrysel" (Dan. $7: 23$, ou vertaling). Merkwaardig genoeg deel die digters dus 'n Bybelse argief, maar seker ook 'n meer populêre raam van apokaliptiese verhale. Deur hierdie handelingsreeks van "die aarde vernietig" te aktiveer, suggereer die digters dalk enigsins dat die kreature inderdaad monsteragtig is en 'n groter bedreiging inhou as wat ' $n$ mens dalk vermoed - of, aan die ander kant, dat hulle 'n veel sterker simboliese waarde het as wat 'n mens by die eerste kyk wil toegee.

Wat in die algemeen dus gebeur, is dat die digters die onbekende kreature probeer beskryf en verstaan in terme van bekende diere of ledemate van diere. Telkens blyk egter dat hierdie patrone en gehele ontoereikend is vir die doel - die kreature weier dikwels om in hierdie bekende patrone ingepas te word. Deur hierdie patrone op te hef of met mekaar te laat bots en die onwaarskynlikheid van die kreature se samestellings op die voorgrond te plaas, gee die digters nie net naam aan die kreature nie, maar maak die kreature ook absurd en ongerymd en daardeur minder bedreigend.

Op 'n tweede vlak pas die digters die kreature in verhale of handelingsreekse (skrippe, scripts ${ }^{5}$ ) uit die alledaagse lewe in. Dit is veral opvallend by Lewis, wat hierdie skrippe meestal ook kernagtig aandui - vergelyk sy benamings vir Canny se stertveertjie soos hierbo (p. 65) aangehaal: hy plaas die veertjie in handelingsreekse soos "die piek van 'n berg bereik", "wind wys", "metamorfoseer tot volwasse padda" en "verjaarsdag vier". Canny se vlerke pas vir hom in die skrip van "skoolkonsert hou". Soos ek reeds uitgewys het, kom die skrip van paring en die laer liggaamlike strata opvallend dikwels voor - vergelyk "besnuffel", "'n nood hê" en "boontjiesopskote los" by Van Coller en "n paringsdans uitvoer" by Viljoen. Hond- en jagtersgedrag is belangrike rame vir die verstaan van Choppy en Wolfie: Van Coller pas Wolfie in die skrip van jag en "skote afvuur" in, en Viljoen vir Choppy in die idee van miere vreet.

5 'n Skrip is 'n raam waarbinne 'n reeks handelingselemente in 'n spesifieke volgorde gerangskik is, soos die bekende reeks handelinge wat 'n mens in 'n restaurant verrig (vgl. Schank \& Abelson, 1977). 
Ander alledaagse skrippe by Van Coller is "beleefd verskoning vra" (Rhino), "steroïede drink", "tv-kyk", "skou, uitstal" (Fishy) en "superheld red vrou in nood" - natuurlik van deel van die skrip van die titel, naamlik "Dracula".

Die aanwesigheid van vlerke aktiveer vir die digters die skrip "vlieg". Viljoen meen dat Rhino en Ostrigy wanhopige pogings aanwend om te vlieg of juis nie te vlieg nie. Lewis laat vir Ostrigy "trap in vlug" en bring Ducky in beweging deur hom in te pas in die skrip "eendjies stap kwaak-kwaak dam toe". Die sterk aanduidings van gans- (of eend-) agtigheid in die kreature trek Lewis in sy "Beskets" saam in 'n sentrale skrip van gansmigrasie. Die klem op vlieg kan in die konteks van die kreature verstaan word as 'n gesamentlike strewe na hoër dinge - skerp in kontras met die dierlikheid en die liggaamlik-laer strata. Daar is skynbaar 'n sterk dialektiek tussen laag en hoog in die kreature aanwesig.

Viljoen herken in Froggies die minder alledaagse skrip van "bedreig met gevaarlike knoetse" en gebruik ook die ou militêre terme van vleëls en bolsters vir hierdie wapens. Hy plaas hulle egter in die skrip van "poëtikale uitsprake maak". Merkwaardig genoeg sien Van Coller ook iets digterliks in Froggies. ' $n$ Ander, minder populêre skrip wat geaktiveer word, is "dink, filosofeer" - naamlik die verwysing na die onbeweeglike by Viljoen (Wolfie) en die verwysing na Sokrates in Lewis se "Beskets".

Oor die algemeen skets die digters egter nie danig dinamiese portrette van die kreature nie. Die gedigte is oorwegend beskrywend en die skrippe wat geaktiveer word, redelik staties. Du Plessis se diere ruik, stink en voel hoofsaaklik. Du Plooy se diere is potensieel baie dinamies ("vlug van voet, van vlerk of vin / skerp geklou en sterk gebou") en daar is sprake van "sien" en "roer", maar die klem val sterk op "verstar", op "gebaken en geborge", op "strak maak en beklem". Die slotskrip is wel weer dinamies: die woord "glip" roep die skrip "vis swem moeiteloos in 'n dam" op. Lewis gee 'n sterk dinamiek aan Ducky en Ostrigy, maar sy beskrywing van Canny is staties. Dracula gaap, hap en byt wel (maar dan met sy oë), maar die slotskrip in sy reeks is "Suid en impotent hang". Van Coller gebruik baie min werkwoorde en dan oorwegend werkwoorde soos "is", "het" of "staan". Sy beskrywing van Fishy bevat byvoorbeeld glad nie 'n werkwoord nie. Sy gedigte bestaan meestal uit lyste eienskappe van die diere en hulle word selde met sterk aktiewe werkwoorde beskryf. Die uitsondering is "besnuffel" in sy portret van Choppy. Viljoen se tekste is vol dinamiese werkwoorde, en hy is ook die digter wat konsekwent probeer om die diere in beweging te sien. Rhino stel hy 
voor as onvergenoeg omdat hy al begin vlieg. Ostrigy trap-trap desperaat en probeer die lug in beur. Ducky voer 'n paringsdans vir die sonneblom uit. Froggies swaai hulle vleëls rond en Fishy verskyn, gluur en wys tande. Selfs Wolfie, wat in sy siening eintlik nie kan beweeg nie, wankel en strek sy poot vooruit. Die enigste een wat nie handel nie, is Canny. Hierdie dinamiese woorde is deel van Viljoen se poging om hom in te leef in die gedagtes van die kreature op grond van hulle gesigsuitdrukkings en iets van hulle wese te probeer vertolk (vgl. sy credo, "artist's statement", in die katalogus; Van der Westhuizen et al., 2007).

Op 'n derde vlak kan 'n mens sien dat die digters 'n beroep doen op gedeelde beeldargiewe of storieargiewe. 6 Van Coller en Viljoen doen 'n beroep op 'n geleerde en literêre argief (as 't ware van Aquinas tot A.G. Visser) en Viljoen ook op 'n mitologiese argief. Dit is egter ook duidelik dat die kreature by die digters 'n gedeelde populêre visuele argief aktiveer, soos blyk uit die verwysings na Frankenstein, superhelde, die Cadillac en tv, lasergewere, Dracula, Medusa, W.P.-kleure, die diereriem en frieskoeikolle. 'n Merkwaardige ooreenkoms is die dier uit die see uit die Bybelse argief wat Lewis en Viljoen in Vampire herken.

\section{Reaksies op die kreature}

Die digters se reaksie op die kreature en die posisie wat hulle sprekers teenoor die diere inneem, is nogal uiteenlopend. Du Plessis se spreker beklemtoon dat die diere hom inspireer tot kreatiwiteit, wat in sy geval veral vermenging en permutasie inhou. Nogtans bly die spreker taamlik op 'n afstand; die diere raak hom nie persoonlik nie, hoewel hulle hom (en die leser saam met hom) uitnooi tot spel.

In teenstelling met hierdie afstandelikheid is die diere vir die spreker in Du Plooy se verse 'n vertrekpunt vir persoonlike inlewing in die kreature, maar ook aanleiding tot oënskynlik persoonlike herinnerings en ' $n$ verwondering aan 'n kind se kyk wat geborge en tog eindeloos is en bewus is van volmaaktheid. Die simbool daarvan is die "skitterend silwer vis diep in die donker dam". Idees van sterkte en tem kom ook na vore. Hierdie oomblik van insig, hierdie beeld van volmaaktheid troos die kyker/leser dalk met die gedagte dat die

6 Met die term argief bedoel ek sowel "'n versameling historiese rekords" as "'n versameling rekenaarlêers, byvoorbeeld vir rugsteundoeleindes" - versamelings, rekords of beelde as 't ware in die brein gestoor. 
gebrokene en wanstaltige (die kreature dus) 'n mens kan stimuleer om die volmaakte te dink.

Soos Du Plooy in haar credo skryf (Van der Westhuizen et al., 2007), gaan poësie vir haar om die patrone en kontoere wat onder die oppervlak van die werklikheid lê; "om 'n bewustheid van wat onder die sigbare laag werksaam is". Die spreker in haar gedigte is (in hierdie simbolistiese trant) veral bewus van die patroon agter die kreature, naamlik die verhouding tussen pa en seun waaruit hulle ontstaan het. Opvallend by Du Plooy is die klem op 'n dieperliggende patroon, naamlik die grensloosheid van die kind se drome en die openheid van sy wêreld wat sterk in kontras staan met die pa wat deure toemaak, grense trek om die kind veilig te hou en wie se drome dan beskryf word as "verstar". Du Plooy se gedigte is gebou rondom die spanning tussen binne en buite: die rame, matryse, houers buite-om wat vryheid en grensloosheid binne moontlik maak. Die dialektiek tussen omraming en vryheid binne die raam is bepalend vir hierdie drie gedigte.

In "Herfs" is die beweging omgekeer: bewus van die tuin as rooster en die boomtakke "soos rag óm asem en ruimtes" staan die karakter op die punt om na 'n nuwe matrys toe te beweeg - deur die begrensings van die bos langs die rivier, oor die rivier en die spoor tot waar die vlakte "oopspoel in stromende son". Sy beweeg in 'n oop ruimte in, maar dié ruimte vorm tog 'n nuwe matrys, 'n nuwe omraming.

In die derde gedig, "Nagnagvers" word hierdie patroon veralgemeen na 'n ander kind toe, wat "gebaken en geborge" lewe binne die beskutting van die stoep omring deur son. Sy kan veilig uitbeweeg in die son en die wonders sien wat tegelyk "klein" en "eindeloos" is. Die sterkes waaraan sy in die nanag dink, is die teenhangers van die kreature, maar veral van die pa van die eerste gedig - groot kragte "wat strak maak en beklem", maar natuurlik ook veilig maak en beskerm; 'n raster, 'n matrys vir die eindeloosheid daarstel. Uit hierdie dialektiek ontwikkel die volmaakte silwer vis, beskut in die dam: die dam vorm 'n klein beskutting, maar is ook eindeloos omdat dit volkome rond is, dit wil sê sonder grens of afbakening.

Van Coller se vernufspoësie bekyk die diere van buite, met die sinies sardoniese blik wat hy, blykens sy credo (Van der Westhuizen et al., 2007), noodsaaklik ag vir afstand, objektiwiteite en realisme. Hy handhaaf deurgaans 'n veilige afstand van hulle. Om die diere met die verstand 'n bietjie klein te kry, met vernuf en geestigheid hulle absurditeite uit te wys, is natuurlik ook 'n soort beswering van 
die bedreiging wat hulle inhou. 'n Mens sou egter ook kon sê dat Van Coller se reaksie, in teenstelling met Du Plooy se soeke na dit wat onder die oppervlak aan die werk is, 'n reaksie op die oppervlakte is wat wegskram van die dieper en ontstemmender implikasies van die kreature.

Viljoen stel 'n objektiewe stem aan die woord wat saam (of soms teen) die kreature se eie stemme praat. Waar die ander digters die kreature van buite betrag, stel Viljoen die meeste van hulle voor as denkende en pratende wesens en probeer om die kreature se binnelewe, denke en emosies bloot te lê. Hy personifieer hulle baie sterk. Sy siening is nie net 'n poging om hulle te verstaan en aan hulle insig in hulle eie hibriede toestand toe te skryf nie, maar ook 'n poging om diepte en menslikheid in die kreature te ontdek - 'n soort empatiese verstaan van hulle ontologiese kondisie, dalk. Hierdie aanslag blyk veral uit die geval van die gansikloop, maar ook by Rhino, Choppy, Fishy, Wolfie en Vampire. Die paddas tree vrolik in gesprek met die leser en verkondig 'n poëtika wat die dubbelslagtigheid van die digterlike woord onderstreep - streel of slegsê is ewe gevaarlik. Samevattend probeer hy ook 'n greep op die kreature kry deur hulle te benoem en te ontleed en dus mak en inheems te maak. Dit is ook 'n vorm van beswering van die bedreiging, al lê hy klem op hulle monsteragtigheid. Hulle word effens spottend betrag, en dit is ook 'n manier om afstand te skep en te behou. Al beskryf hy die kreature as 'n nuwe bedreigende diereriem, is Viljoen se strak gekonsentreerde gedigte en die reekstitel ook maniere om te omlyn en afstand te skep - maniere om die bedreiging van die diere, ondanks ' $n$ besef dat hulle die aanvaarde werklikheid bevraagteken, nie te naby toe te laat nie.

Soos Du Plooy speel Lewis ook in op die ouer-kindkonteks, maar dan veel meer implisiet en sonder donker konnotasies. Dit is opvallend dat hy ook heelwat Gestalts en skrippe uit die kinderwêreld met die kreature assosieer - die kinderliedjie, koushandpop, die lelike eendjie, kersie op 'n koek, verjaardaghoed, skoolkonsert. Hy maak onder andere Canny se stertjie kleiner en minder bedreigend - maar ook feesteliker. Skerp in teenstelling met hierdie kinderdinge wat die kategorieë ondermyn en die diere besweer en veilig maak, beklemtoon hy met die klem op oë en bekke juis die bedreiging van Vampire. Hy voer dit na 'n apokaliptiese visioen van die dier uit Daniël wat verwoes en vertrap.

Die spreker in Lewis se gedigte is die een wat die diere die naaste aan sy psige toelaat en in die slotgedig eksplisiet rekenskap gee van die uitwerking van die diere in die poging om aan hulle stem te gee. 
Hulle dring sy psige binne, "verkens" hom, ry hom en voer hom in die sentrale beeld van gansmigrasie na Oos-Europa toe, waarvan katedrale, pyporrels, Dracula, Xar en Dostoyevsky vir hom indekse is. Die gedig beskryf ook 'n proses van die disintegrasie van die ek die ek "verdamp soos 'n swerm ganse".

Die spreker aktiveer hier ook die skrip van perdry baie sterk as hy homself beskryf as "besaal gemonteer gestang in die bek". Die diere verdierlik hom, ry hom letterlik, tem hom, spook by hom. Hulle "verdoos" hom, met ander woorde maak hom gek, belaglik en impotent en bring hom in opstand, as ek die slot reg verstaan, teen die Westerse denktradisie soos vergestalt in Sokrates. In die slot van die gedig hang die spreker homself aan sy klimtou en verdwyn dus as 't ware heeltemal as "ek" uit die gedig. Die diere het 'n baie sterk vernietigende uitwerking op sy psige en sy hele Westerse manier van dink. Hy dwing hom om uit te reik na iets anders toe. By al die negatiewe effekte wat die diere op die spreker het, is die kreatiewe uitbreidings en ondermyning van die Gestalts in die tekste ekspressies van die digter se credo (Van der Westhuizen et al., 2007), naamlik "om elemente uit die wêreld te reflekteer in 'n karnavalspieël".

Ten spyte van al die ooreenkomste, is daar dieperliggend dus groot verskille in die digters se oogmerke en in hulle aannames oor sowel die kreature as oor hulle eie skryfwerk.

\section{Die kreature en kreatiwiteit}

Kreatuur en kreatiwiteit veronderstel albei iets wat geskep is - uit Latyn creatio, "ek skep". Hoe het die digters hulle gedigte gemaak? Was dit 'n kreatiewe proses of 'n doelbewuste maakproses? Kan 'n mens uit die resultate iets van hulle kreatiewe proses aflei?

Die risiko is natuurlik baie groot dat hierdie soort poësie net maaksels kan wees - woordkonstruksies wat nie werklik poësie word nie. By Lewis is daar 'n sterk klem op die fabrisering van sy tekste. Van Coller skryf doelbewus vernufspoësie. Woordspel en klankspel is, soos uit baie van die gedigte blyk, egter belangrike verkennende, kreatiewe instrumente.

Dit is duidelik dat die digters baie kreatiwiteit aan die dag gelê het om die kreature te benoem en in te pas in bekende patrone, terwyl hulle tog ook die ontoepaslikheid van die patrone erken het. Kreatiwiteit begin dus meestal by die gewone en bekende dinge, maar die digters trek dit ver deur na die ongewone toe. Heelwat 
werk is gedoen om patrone te herken: gehele, patrone, rame, skrippe en argiewe. Byna al die digters het die variasies van ledemate van die kreature probeer naboots in taal - in die vorm van die taal, in ongewone samestellings en afleidings. Besonder kreatief is Lewis se oproep van 'n uitbreidende reeks van patrone of die vestiging en ondermyning van ' $n$ patroon (veral die patroon van die bokserhond in Canny).

Samevattend kan kreatiwiteit hier gesien word as 'n mengsel van ikonisering, patroonherkenning (die oproep van bekende rame, skrippe en argiewe) en benoeming en ontnoeming (pogings om die diere vindingryk te verbaliseer).

Om sin te maak van die kreature het die digters hulle sterk gepersonifieer (al kry ons die omgekeerde in Lewis se "Beskets"), maar daaruit blyk ook dat die intrek van die diere in die gewone begripsraamwerke in, ook hulle vreemdheid en absurditeit op die voorgrond plaas. Die digters (met die uitsondering van Lewis, dalk) wend eintlik hulle kreatiwiteit aan om die kreature tog as bekend voor te stel en hulle sodoende belaglik te maak en te probeer besweer. Vandaar die opvallende rol wat die laer liggaamstrata speel. Die digters kan, by wyse van spreke, hulle lag vir die diere nie hou nie. Nogtans is daar 'n ewe sterk omgekeerde tendens, naamlik om in die diere ook 'n strewe na die verhewene en na transendensie te herken transendensie sowel in 'n gevaarlike as 'n sublieme sin.

Net soos die kreature is die gedigte gemaak: hulle is verstandswerk, rasionele konstruksies. Dit blyk onder andere uit die logika van mutasies en kombinasies van die soorte pote in die sketse. Hierdie droom van die rede skep bedreigende maaksels, want hulle wyk af van die bekende. In die gedigte word die maakproses onder andere nageboots met mutasies van morfologiese vorms. Die droom van 'n rasionele soort ars combinatoria (die kuns van die maak van variasies en kombinasies) produseer in sommige gevalle (in Lewis en Viljoen se sienings van Vampire veral) ook monsters, net soos in Goya se uitbeelding van die gevaarlike droom van die rede in Capricho 43. By Du Plooy vind ons egter die omgekeerde: die gemaaktheid lei nie tot monsters nie, maar die makmaak, die bewustelike herskik, die skep van rame waarbinne die kind veilig gestel word. Die takke beskryf Du Plooy byvoorbeeld as "verdigtings soos rag óm asem en ruimtes" ("Herfs", vers 6). Die gemaaktheid is ' $n$ beswerende en beskermende raster waarbinne vryheid en volmaaktheid moontlik is, soos die beeld van die vis in die slot suggereer. 


\section{Slotsom}

In Nederlandse vertaling lui die woorde aan die begin van Horatius se Ars poetica, wat ek as motto bo-aan hierdie artikel aangehaal het, soos volg:

Een mensenhoofd geschilderd op een paardenek,
een verenpracht, aan ledematen vastgeplat
van elke soort, zodat een vrouw, van boven mooi,
beneden uitloopt in ene grauwe vissestaart:
vrienden, wie lacht er niet wanneer hij dat bekijkt?

(Horatius, 1990: v. 1-6.)

Ongewone of onvanpaste kombinasies is volgens Horatius lagwekkend. Daarmee dring hy eintlik aan op dit wat gepas is. Die kunstenaar moet dus net skryf of skilder wat voldoen aan die eis van die werklikheid en behoort nie die grense van die aanvaarde te oorskry nie. Hy moet dus voldoen aan 'n eis van dekorum: die gepaste, die werklike.

Dit is duidelik dat die kreature Horatius se dekorum-eis enersyds heeltemal ignoreer, maar andersyds ook navolg. Die digters personifieer die diere - en die diere verdierlik die digter in Lewis se "Beskets" - maar daar is net een kreatuur wat werklik die dierlike en die menslike vermeng, en dit is Vampire. Miskien is hy daarom ook die bedreigendste.

Die digters kan hulle lag soms nie hou nie - al is hulle lag dikwels ook maar een van die talle maniere om hulle ongemaklikheid met hierdie buitengewone of abnormale kreature te probeer besweer. Soos gestel, boots die digters die variasiespel van die kreature morfologies na en benoem en ontnoem hulle binne alledaagse patrone. Hulle pas die diere egter ook in groter rame in om hulle verstaanbaar te probeer maak - 'n poging wat dikwels net deels slaag, omdat die diere nie heeltemal in die gewone ingepas kan word nie. Desondanks bly die idee van dekorum, naamlik om nie te ver van die gewone af te wyk nie, deurgaans as 'n soort beveiligende grens aanwesig.

\section{Geraadpleegde bronne}

BAKHTIN, M. 1984 [1965]. Rabelais and his world. Trans. by Helene Iswolsky. Bloomington: Indiana University Press.

BYBEL, DIE. 1965. Die naslaan-Bybel. Kaapstad: Die Bybelgenootskap van Suid-Afrika.

GOLDBERG, B.S., ed. 2008. Barry's temple of Godzilla. http://www.godzillatemple.com/index2.htm. Date of access: 24 Jul. 2008. 
GREYLING, F. \& MARLEY, I. 2009. Op die spoor van kreatiewe kreature: projekbeskrywing. Literator, 30(1):1-29.

HOFMAN, W. 2003. Goya; "To every story there belongs another." Trans. by David H. Wilson. London: Thames \& Hudson.

HORATIUS, 1990. [c.20 BC]. Ars poetica. Trans. by P.H. Schrijvers. Amsterdam: Polak \& Van Gennep.

LOUW, N.P. VAN WYK. 1981. Versamelde gedigte. Kaapstad: Tafelberg.

MERRIAM-WEBSTER ONLINE DICTIONARY. 2009. Merriam-Webster Online. http://www.merriam-webster.com/dictionary/gestalt. Date of access: 26 Apr. 2009.

MINSKY, M. 1975. A framework for representing knowledge. (In Haugeland, J., ed. 1981. Mind design: philosophy, psychology, artificial intelligence. Cambridge: MIT. p. 95-128).

SCHANK, R.C. \& ABELSON, R.P. 1977. Scripts, plans, goals and understanding. Hillside: Erlbaum.

VAN DER WESTHUIZEN, C.E., MARLEY, I.R., GREYLING, S.F. \& COMBRINK, A. 2009. Op die spoor van kreatiewe kreature: digitale katalogus, weergawe 2.0. [CD-ROM]. Potchefstroom: Vakgroep Grafiese Ontwerp.

VILJOEN, H. 1987. Metafore en rame. Tydskrif vir literatuurwetenskap, 3(2):5777.

\section{Kernbegrippe:}

ekfrastiese poësie

kreatiwiteit

rame, skrippe, argiewe

woord-en-beeldverhoudings

\section{Key concepts:}

creativity

ekphrastic poetry

frames, scripts, archives

word and image relations 
